\title{
Successional variation in carbon content and wood specific gravity of four tropical tree species
}

\author{
Variación en el contenido de carbono y peso específico de una sucesión \\ de cuatro especies arbóreas tropicales
}

\author{
Marcela Navarro $^{\text {a, }}$ Róger Moya ${ }^{\text {a*, Robin Chazdon }}{ }^{\text {b, Edgar Ortiz a, Braulio Vilchez }}{ }^{\text {a }}$

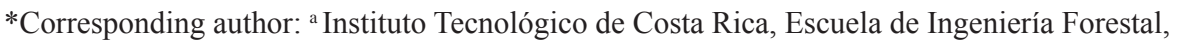 \\ Apartado 159-7050, CIIBI-ITCR, Cartago, Costa Rica, rmoya@itcr.ac.cr \\ ${ }^{\mathrm{b}}$ University of Connecticut, Department Ecology and Evolutionary Biology, Storrs, CT 06269-3043, U.S.A.
}

\begin{abstract}
SUMMARY
The carbon content and the specific gravity of wood are indirect indicators of carbon storage capacity of trees. We monitored carbon content in four tropical species (Apeiba tibourbou, Guatteria amplifolia, Hyeronima alchorneoides and Tetrathylacium macrophyllum) in four different succession stages (5-15 years, 15-30 years, 30-50 years and old-growth forest of approximately 80 years old) in humid lowland forests in Costa Rica's Osa Peninsula. Carbon content varied significantly, from 0.41 to 0.51 , across species and across successional stages, but it was not affected by diameter at breast height in any species. Mean wood specific gravity varied 3-fold across species, from 0.18 (A. amplifolia) to 0.54 (H. alchorneoides), whereas carbon content ranged from 0.40 (A. amplifolia) to 0.51 (H. alchorneoides). Specific gravity varied significantly (from 0.41 to 0.55 ) across successional stages only in G. amplifolia, whereas carbon content was different in some successional stages in A. tibourbou, H. alchorneoides and T. macrophyllum. Specific gravity and carbon content were correlated only in T. macrophyllum. Finally, results suggest that carbon content pertains to each species and it is affected by the succession stage.
\end{abstract}

Key words: secondary forests, carbon, wood density, corredor biológico Osa, climate change.

\section{RESUMEN}

El contenido de carbono y el peso específico básico de la madera son indicadores indirectos de la capacidad de almacenamiento de carbono de los árboles. La variación del contenido de carbono se monitoreó en cuatro especies tropicales (Apeiba tibourbou, Guatteria amplifolia, Hyeronima alchorneoides y Tetrathylacium macrophyllum) en cuatro estados sucesionales (5-15 años, 15-30 años, 30-50 años y bosque primario, de aproximadamente 80 años) de un bosque húmedo de la Península de Osa en Costa Rica. El contenido de carbono varió significativamente, de 0,41 a 0,51 , en tres especies estudiadas y los estadios sucesionales, pero este no fue afectado por el diámetro a la altura del pecho en ninguna especie. El promedio de peso específico básico varió en las diferentes especies, de 0,18 (A. amplifolia) a 0,54 (H. alchorneoides), mientras que el contenido de carbono varío de 0,40 (A. amplifolia) a 0,51 (H. alchorneoides). El peso específico básico varió significativamente (de 0,41 a 0,55 ) en los diferentes estadios sucesionales solamente en G. amplifolia, mientras que el contenido de carbono fue diferente en algunos estadios sucesionales de A. tibourbou, H. alchorneoides y T. macrophyllum. El peso específico básico y el contenido de carbono fueron correlacionados solamente en T. macrophyllum. Finalmente, de los anteriores resultados sugieren que los patrones de variación son propios de cada especie y estos son afectados por los diferentes estadios sucesionales.

Palabras clave: carbono, corredor biológico Osa, cambio climático, bosque secundario, peso específico básico.

\section{INTRODUCTION}

Globally, tropical forests constitute a disproportionately large carbon pool, containing roughly $40-50 \%$ of all carbon in terrestrial biomass, despite covering only $7-10 \%$ of land area (Martin and Thomas 2011). The specific gravity of wood is closely linked with mechanical properties of wood and with carbon storage (Williamson and Wiemann 2010, Martin and Thomas 2011). Recent studies have shown that carbon content and specific gravity of tropical species vary with tree size, age and within tree (Williamson and Wie- mann 2010), among regions (Chave et al. 2006, Nogueira et al. 2008), among species (Elias and Potvin 2003), among successional stages (Vaccaro et al. 2003) and among other factors as temperature, site quality, species and trees per hectare (Martin and Thomas 2011).

Tropical forest ecosystems undergo secondary succession in response to natural disturbances (hurricanes and tree falls due to senescence) or anthropogenic disturbances such as logging and conversion of forests into pasture and agricultural lands around the world. The fast growth of species or colonizers species in the initial stages of succes- 
sion leads to high rates of aboveground production and storage of carbon and nutrients lost during deforestation and subsequent land uses. Pan et al. (2011) estimated that tropical re-growth forest worldwide may sequester between 1.57 and $1.72 \mathrm{Pg}$ of carbon each year. Secondary forests in tropical regions play a critical role in mitigating increasing levels of atmospheric $\mathrm{CO}_{2}$ by assimilating and storing carbon in the terrestrial biosphere (Hughes et al. 1999).

The role of species and successional differences in carbon content or specific gravity values in affecting estimates of biomass and carbon storage remains poorly understood (Vaccaro et al. 2003). Successional changes in floristic composition may strongly influence forest carbon dynamics, and failure to account for species differences in specific gravity and carbon content can lead to biased estimates of carbon storage in secondary tropical forest ecosystems. Generally, woody tissues of trees $>10 \mathrm{~cm}$ in diameter at breast height comprise the largest carbon content (approximately $95 \%$ ) of biomass in tropical forests (Chave et al. 2006). Yet, of all wood functional traits only specific gravity has been widely compared among tropical tree species (Chave et al. 2006). Few studies have examined differences in species-specific wood carbon content data in tropical trees (Martin and Thomas 2011). Further, limited research focuses on the relationship between carbon content and specific gravity across different successional stages. Many studies have shown that rates of biomass accumulation and carbon storage change during tropical forest succession, but few studies have accounted for variation in carbon content and specific gravity of trees across different successional stages for different species.

Most ecosystem-level carbon accounting approaches assume that carbon content is a constant 50 percent of aboveground biomass (Martin and Thomas 2011). Despite this widespread assumption, it is likely that carbon content varies during forest succession due to changes in species composition. Moreover, different studies have shown that species vary in wood carbon content (Chave et al. 2006, Elias and Potvin 2003, Vaccaro et al. 2003, Figueroa et al. 2005). Empirical data from stem cores of 59 Panamanian rainforest tree species demonstrate that species mean wood carbon content varied from 41.9-51.6 \%, with an average of $47.46 \%$ (Martin and Thomas 2011).

Clearly all above studies show that carbon content varies among tree species and limited studied have yet examined how carbon content and specific gravity vary within species across successional stages. The objective of this study is to examine carbon content and specific gravity across species, successional stages and tree size classes and to establish the relationship of carbon content and specific gravity among four tree species (Apeiba tiborbou Spruce ex Benth., Guatteria amplifolia Triana et Planch., Hyeronima alchorneoides Allemao, and Tetrathylacium macrophyllum Poepp.) across different successional stages of natural forests in Costa Rica. This is the first study to compare carbon content and specific gravity across spe- cies, successional stages and tree size classes, providing new insights into the complexity of monitoring carbon storage during secondary succession in tropical forests.

\section{METHODS}

Geographical location of the study site. The sample sites are located in the Osa Peninsula (between $8^{\circ} 21^{\prime} 07^{\prime \prime} \mathrm{N}$ to $8^{\circ} 46^{\prime} 56^{\prime \prime} \mathrm{N}$ and $83^{\circ} 14^{\prime} 28^{\prime \prime} \mathrm{W}$ to $83^{\circ} 45^{\prime} 24^{\prime \prime} \mathrm{W}$ ) in the southern area of the province of Puntarenas, Costa Rica. The region has a very humid and warm climate; the dry season is short (approximately 35 days) from January to March, the average annual temperature varies between 23 and $27^{\circ} \mathrm{C}$, and the average annual precipitation varies between 3,420 and $6,840 \mathrm{~mm}$ (table 1 ).

Forest characteristics. The study sites are classified as tropical wet forest (T-wf) and premontane rain forest basal belt transition (P-rf-P6). Trees were sampled in 14 permanent monitoring plots in four different sectors of the Osa Peninsula (table 1). In each sector, private forest patches were located in four different succession stages and in those patches, permanent monitoring plots were established within an area of 5,000 $\mathrm{m}^{2}(50 \times 100 \mathrm{~m})$. The search for the different succession stages was carried out using the Costa Rica vegetation coverage map for the year 2005 (Calvo and Sánchez 2007) and field verification was done through visits to the different sites. Forest areas were classified into four succession stages (table 2): 5-15 years (three plots); 15-30 years (three plots); 30-50 years (three plots); and old-growth (five plots).

Selection of species and wood sampling. We selected four species that were the only species that occurred in all four successional stages and in all plots: Apeiba tibourbou (Tiliaceae), Guatteria amplifolia (Annonaceae), Hyeronima alchorneoides (Euphorbiaceae) and Tetrathylacium macrophyllum (Flacourtiaceae). The number of sampled trees varied across each plot, because of differences in species abundance (table 1). All trees of each species in each plot were sampled. The minimum sampled diameter was $7.5 \mathrm{~cm}$. Two samples were extracted (one in the northern side and one in the eastern side) from each tree through the use of a Pressler wood drill; two cylinders of $5 \mathrm{~mm}$ in diameter at breast height were taken. Individual cores varied between 4 and $12 \mathrm{~cm}$ in length, depending on the tree diameter. The core went through the pith in trees with diameters inferior to $15 \mathrm{~cm}$. Heartwood was present in the samples of H. alchorneoides and G. amplifolia. Two cores from each tree were kept in plastic bags that did not allow for air circulation, thus avoiding drying and dimensional change. Two cores were put together in one single sample for the determination of wood specific gravity and carbon content. Our total sample comprised 64 samples from four succession stages, four trees per species in each stage and 1 combined sample per tree (one sample extracted from two cylinders). 
Table 1. Succession stadium type, life zone, and elevation of 14 permanent study plots in the Osa Peninsula in Puntarenas, Costa Rica. Tipo de estadio sucesional, zona de vida y elevación de las 14 parcelas permanentes de medición estudiadas en la Península de Osa- Puntarenas, Costa Rica.

\begin{tabular}{|c|c|c|c|c|c|c|c|c|}
\hline Name & $\begin{array}{l}\text { Succession stage } \\
\text { (years) }\end{array}$ & $\begin{array}{c}\text { Plot } \\
\text { number }\end{array}$ & $\begin{array}{c}\text { Number of sampled } \\
\text { individuals }\end{array}$ & Sector & $\begin{array}{l}\text { Tree per } \\
\text { hectare }\end{array}$ & $\begin{array}{l}\text { Basal area } \\
\left(\mathrm{m}^{2} \mathrm{ha}^{-1}\right)\end{array}$ & $\begin{array}{l}\text { Life } \\
\text { zone }\end{array}$ & $\begin{array}{l}\text { Elevation } \\
\text { (m) }\end{array}$ \\
\hline & $5-15$ & 7 & 2 & Matapalo & 739 & 10.10 & T-wf* & 305 \\
\hline \multirow[t]{3}{*}{ Stage 1} & $5-15$ & 14 & 5 & Los Mogos & 536 & 7.32 & T-wf* & 245 \\
\hline & $5-15$ & 17 & 9 & Los Mogos & 1,036 & 18.36 & T-wf* & 60 \\
\hline & $15-30$ & 5 & 3 & Río Piro & 1,028 & 20.68 & T-wf* & 39 \\
\hline \multirow[t]{3}{*}{ Stage 2} & $15-30$ & 9 & 3 & Matapalo & 1,164 & 19.58 & T-wf* & 242 \\
\hline & $15-30$ & 18 & 10 & Los Mogos & 1,202 & 23.70 & T-wf* & 60 \\
\hline & $30-50$ & 4 & 2 & Río Piro & 1,002 & 25.93 & T-wf* & 38 \\
\hline \multirow[t]{4}{*}{ Stage 3} & $30-50$ & 6 & 4 & Río Piro & 1,206 & 26.16 & T-wf* & 39 \\
\hline & $30-50$ & 11 & 10 & Los Mogos & 1,484 & 30.82 & P-rf** & 104 \\
\hline & old-growth forest & 2 & 2 & Río Piro & 870 & 35.68 & T-wf* & 47 \\
\hline & old-growth forest & 3 & 1 & Río Piro & 776 & 32.74 & T-wf** & 38 \\
\hline \multirow[t]{3}{*}{ Stage 4} & old-growth forest & 8 & 3 & Matapalo & 788 & 38.15 & T-wf* & 322 \\
\hline & old-growth forest & 10 & 8 & Bahía Chal & 1,258 & 32.03 & T-wf* & 290 \\
\hline & old-growth forest & 13 & 2 & Los Mogos & 1,156 & 39.63 & T-wf* & 200 \\
\hline
\end{tabular}

Source: Adapted from Morales (2010).

Legend: *T-wf: Tropical wet forest and **P-rf-P6: Premontane rain forest, basal belt transition.

Table 2. Characteristics of succession stage studied in the Osa Peninsula in Puntarenas, Costa Rica.

Características de los estadios sucesionales estudiados en la Península Osa-Puntarenas, Costa Rica.

\begin{tabular}{cllc}
\hline Stadium & Name & \multicolumn{1}{c}{ Description } & Amount of plots \\
\hline 1 & $5-15$ years & $\begin{array}{l}\text { Corresponds to areas previously devoted to pastures that were abandoned } \\
\text { from 5 to 15 years ago giving space to an early stage }\end{array}$ & 3 \\
\hline 2 & $15-30$ years & $\begin{array}{l}\text { As with the former stage, areas were devoted to pastures abandoned between } \\
15 \text { and 30 years ago. }\end{array}$ & 3 \\
\hline 3 & $30-50$ years & $\begin{array}{l}\text { Once again, areas were devoted to pastures over 30 years ago and therefore, } \\
\text { they are considered as mature secondary forests. }\end{array}$ & 5 \\
\hline
\end{tabular}

Determination of the carbon content. First, each sample was submitted to a process to eliminate extractives before determining carbon content, as these wood components can affect carbon content values. Extractives are residual deposits of physiological processes of cells and they tend to considerably increase heat during combustion (Thomas and Malczewski 2007). Extractives were separated from wood, carrying out the methodology proposed by ASTM D1105-96 (ASTM 2003a), which consists of performing a constant wash up with an ethanol and toluene solution during 4 hours and then a wash up with boiling distilled water for 1 hour. We used the calorimetric method proposed by Nelson and Sommers (1975) to measure carbon content. This method is based on determining the amount of total energy an organic material emits. In this case, it was determined by Parr's calorimetric using the ASTM D-5865
(ASTM 2003b) standard. The energy required by plants in the photosynthesis process to fix a carbon mol in organic molecules is $\Delta \mathrm{G}=4.5 * 10^{5} \mathrm{~J} \mathrm{~mol}^{-1}$ (Nelson and Sommers 1975). Hence, carbon content was calculated considering the calorific capacity determined in Parr's calorimetric, the amount of moles the sample has, and the use of the amount of energy to fix carbon per plant (equation 1):

$C C=\left[\frac{\left(\frac{\text { Gross Calorific Value } * 4.1868}{4.5 * 10^{5}}\right) * 12.0107}{S w}\right]$

Where, $\mathrm{CC}=$ carbon content. Gross calorific value in $\mathrm{J} \mathrm{g}^{-1}$. $\mathrm{Sw}=$ sample weight $(\mathrm{g})$ (adapted from Cubero and Rojas 1999). The 12.0107 value represents the carbon molar mass. 
For gross calorific value determination, samples were grinded and their extractives were taken out. Then, samples were dried up to 0 percent moisture content and afterwards sieved up from 250 to $420 \mu \mathrm{m}$ (60 and 40 mesh) size particulates. Subsequently, the screened sample was divided into three sub-samples and these sub-samples were measured for gross calorific value.

Determination of specific gravity. This parameter was determined for the two samples obtained from diameter at breast height of each tree $(1.3 \mathrm{~m}$ height): one in the northern position and one in the eastern position. The specific gravity value determined was the relation between dry weight and the relation of its volume in the green condition, which is called basic specific gravity (ASTM 2003c). To do this, the green volume of samples taken per tree was determined. Due to the $5 \mathrm{~mm}$ diameter cylinders, volume was determined by equation 2 . Then, samples were dried to 0 percent moisture at $103{ }^{\circ} \mathrm{C}\left(217^{\circ} \mathrm{F}\right)$ for 24 hours, and weighted using an analytical balance. Specific gravity of wood was calculated according to equation 3 .

$$
\begin{aligned}
& \mathrm{Gv}=\left[\Pi *\left(\frac{\mathrm{d}}{2}\right)^{2}\right] * \mathrm{I} \\
& \mathrm{SG}=\frac{\mathrm{W}_{0}}{\mathrm{G}_{\mathrm{v}}}
\end{aligned}
$$

Where, $G v=$ green volume $\left(\mathrm{cm}^{3}\right) . d=$ sample diameters (cm). $l=$ sample length $(\mathrm{cm}) . S G=$ specific gravity. $W_{0}=$ dry weight $(0 \%$ moisture content). $\Pi=3.14$.

Data analyses. First, we averaged the two measurements for specific gravity and the three sub-samples of carbon content values from each tree. Average specific gravity and carbon content from all sampled trees and coefficients of variation were determined too (standard deviation*100/average value). We used two-way analysis of variance (2-way ANOVA) with species and successional stages as factors and diameter as a covariate to evaluate the effect of these main factors on variation in specific gravity and carbon content. Tree diameter was used as co-variable due to its relation to these parameters. The difference between the averages of these parameters was applied to Tukey's range test with a confidence level between 95 and 99 percent. A second statistical analysis applied was that of regression between specific gravity and carbon content as dependent variables and diameter as independent variable. Correlation analysis was used to establish whether there is a correlation between carbon content and specific gravity within each species.

\section{RESULTS}

Averages of specific gravity and carbon content. The mean specific gravity per individual tree varied 3-fold across species and the lowest was for A. tibourbou (0.18) and the highest for $H$. alchorneoides (0.55). The species with the greatest variation of specific gravity is A. tibourbou with a coefficient of variation of $23.79 \%$ and the one with the lowest variation was $T$. macrophyllum with a coefficient of variation of $8.8 \%$. Mean specific gravity for A. tibourbou was significantly lower $(P<0.05)$ than for the other species, and mean specific gravity for G. amplifolia was significantly higher than that for A. tibourbou, but lower than for H. alchorneoides and T. macrophyllum (table 3). $H$. alchorneoides and T. macrophyllum had the highest specific gravity but did not differ significantly from each other $(P>0.05$; table 3$)$.

Average carbon content presented low variation among species, though the lowest was also for A. tibourbou (0.40) and the highest for H. alchorneoides (0.51). Apeiba tibourbou exhibited the greatest carbon content variation (coefficient of variation of $25.78 \%$ ), whereas H. alchorneoides showed the lowest coefficient of variation of $11.68 \%$ (table 3). Apeiba tibourbou was significantly lower in carbon content than the other three species $(P<0.05$, table 3$)$, which did not differ significantly from each other $(P>0.05)$.

Effect of diameter on specific gravity and on carbon content. The regression analysis showed that specific gravity in A. tibourbou and T. macrophyllum varied significantly with diameter at breast height $(\alpha<95 \%$; figures 1A and 1D), whereas G. amplifolia and H. alchorneoides did not show a significant effect of diameter at breast height on specific gravity (figures 1B and 1C). Apeiba tibourbou shows a linear increase in specific gravity with diameter; whereas T. macrophyllum showed a slight increase in specific gravity with diameter up to $15 \mathrm{~cm}$. In contrast, carbon content did not vary significantly with diameter for any species (figure $2, P>0.05$ ).

Difference of specific gravity and carbon content tendency among succession stages. Species and the_successional factor were significant and covariate diameter at breast height, which is an indicator of tree age, was significant in specific gravity (table 4). Species presented differences in the different succession stages, and the successional trends varied across species. The specific gravity decreased from early successional to primary forest in A. tibourbou and $H$. alchorneoides (table 3 ). But specific gravity was the highest in 15-30 stage in G. amplifolia and the lowest in primary forest. The 5-15 year stage does not differ statistically from the 15-30-year one and the 30-50-year stage in T. macrophyllum (table 3), probably influenced by diameter at breast height effect (figure 1D).

The carbon content of 5-15 and 15-30 stages was statistically different than that of other stages in almost all the studied species. But there are no significant differences in carbon content in the $>30$ and primary forest stages (table 3 ). The species with the highest coefficient of variation of carbon content was A. tibourbou with $38.10 \%$ in the primary fo- 
Table 3. Specific gravity and carbon content of wood from four forest species in four successional stages from tropical forests in the Corredor Biológico Osa, Costa Rica.

Peso específico básico y fracción de carbono de la madera de cuatro especies forestales en cuatro estadios sucesionales en el Corredor Biológico Osa, Costa Rica.

\begin{tabular}{lclll}
\hline \multicolumn{1}{c}{ Species } & Succession stage (years) & $\begin{array}{c}\text { Diameter at breast } \\
\text { height }(\mathrm{cm})\end{array}$ & Specific gravity & $\begin{array}{c}\text { Carbon } \\
\text { content }\end{array}$ \\
\hline Apeiba tibourbou & Average of all stage & $28.62^{\mathrm{a}}$ & $0.18^{\mathrm{a}}(23.79)$ & $0.40^{\mathrm{a}}(25.78)$ \\
Guatteria amplifolia & & $23.74^{\mathrm{b}}$ & $0.41^{\mathrm{b}}(12.02)$ & $0.49^{\mathrm{b}}(18.84)$ \\
Hyeronima alchorneoides & & $29.34^{\mathrm{a}}$ & $0.55^{\mathrm{c}}(15.41)$ & $0.51^{\mathrm{b}}(11.68)$ \\
Tetrathylacium macrophyllum & & $11.77^{\mathrm{c}}$ & $0.54^{\mathrm{c}}(8.8)$ & $0.48^{\mathrm{b}}(12.78)$ \\
\hline Apeiba tibourbou & $5-15$ & $36.45(24.24)$ & $0.22^{\mathrm{a}}(18.84)$ & $0.34^{\mathrm{a}}(29.4)$ \\
& $15-30$ & $35.68(8.28)$ & $0.19^{\mathrm{b}}(23.95)$ & $0.42^{\mathrm{b}}(14.2)$ \\
\hline Guatteria amplifolia & $30-50$ & $29.08(3.60)$ & $0.18^{\mathrm{b}}(8.14)$ & $0.43^{\mathrm{b}}(21.18)$ \\
& old-growth forest & $13.28(25.89)$ & $0.14^{\mathrm{c}}(22.56)$ & $0.42^{\mathrm{b}}(38.1)$ \\
\hline Hyeronima alchorneoides & $5-15$ & $12.05(28.64)$ & $0.43^{\mathrm{ab}}(7.99)$ & $0.41^{\mathrm{a}}(10.81)$ \\
& $15-30$ & $17.40(32.88)$ & $0.46^{\mathrm{b}}(3.52)$ & $0.53^{\mathrm{b}}(14.38)$ \\
& $30-50$ & $15.18(35.31)$ & $0.41^{\mathrm{ac}}(8.09)$ & $0.55^{\mathrm{b}}(11.2)$ \\
& old-growth forest & $10.33(19.63)$ & $0.36^{\mathrm{d}}(14.76)$ & $0.45^{\mathrm{a}}(25.15)$ \\
\hline Tetrathylacium macrophyllum & $5-15$ & $37.73(7.07)$ & $0.60^{\mathrm{a}}(14.47)$ & $0.50^{\mathrm{a}}(7.44)$ \\
& $15-30$ & $39.38(31.93)$ & $0.53^{\mathrm{b}}(21.62)$ & $0.48^{\mathrm{a}}(17.46)$ \\
& $30-50$ & $11.50(57.01)$ & $0.55^{\mathrm{b}}(17.01)$ & $0.54^{\mathrm{b}}(6.73)$ \\
& old-growth forest & $11.88(30.87)$ & $0.53^{\mathrm{b}}(10.45)$ & $0.52^{\mathrm{ab}}(13.91)$ \\
\hline
\end{tabular}

Legend: averages with equal letters do not present significant differences. Determined at $P>0.01$. The values in square parenthesis represent minimum and maximum values and normal parentheses represent variation coefficients.

rest succession stage. The species with the lowest variation is $H$. alchorneoides with a coefficient of variation of $6.73 \%$ in the older-than-30 year stage.

When evaluating the influence of specific gravity on carbon content through the regression analysis, it was shown that only the carbon content in T. macrophyllum was significantly affected $(P<95 \%)$ by specific gravity (figure 3D). When increasing specific gravity, carbon content also increases $\left(\mathrm{R}^{2}=0.68\right)$. The other species had no relation whatsoever between these two variables (figures 3A, 3B and 3C).

The nonexistent relation between specific gravity and carbon content observed in A. tibourbou, G. amplifolia and $H$. alchorneoides (figures $3 \mathrm{~A}, 3 \mathrm{~B}$ and $3 \mathrm{C}$ ) and the relationship found in T. macrophyllum must be considered as highly important in future carbon determinations; not only in its fraction of the biomass, but also in the amount of carbon stored in a tree. In the case of species that do not show any relation to specific gravity, the future carbon content or stored carbon assessment is simply using the carbon content value obtained in the present study and not considering the possible variation of specific gravity for that species due to the nonexistent relation between those parameters. In future determinations of carbon content in T. macrophyllum, the specific gravity effect must be considered. For the carbon content correction by specific gravity, the best adjustment obtained equation can be used (figure 3D).

\section{DISCUSSION}

The low specific gravity values found in A. tibourbouand G. amplifolia (table 3) can be explained by the fact that these durable heliophytes colonize forest clearings and deforested areas and exhibit high growth rates. Apeiba tibourbou and G. amplifolia had higher diameter increments in relation to H. alchorneoides and T. macrophyllum, especially during early stages of succession ${ }^{1}$. Variation in

\footnotetext{
1 Robin Chazdon, unpublished data.
} 

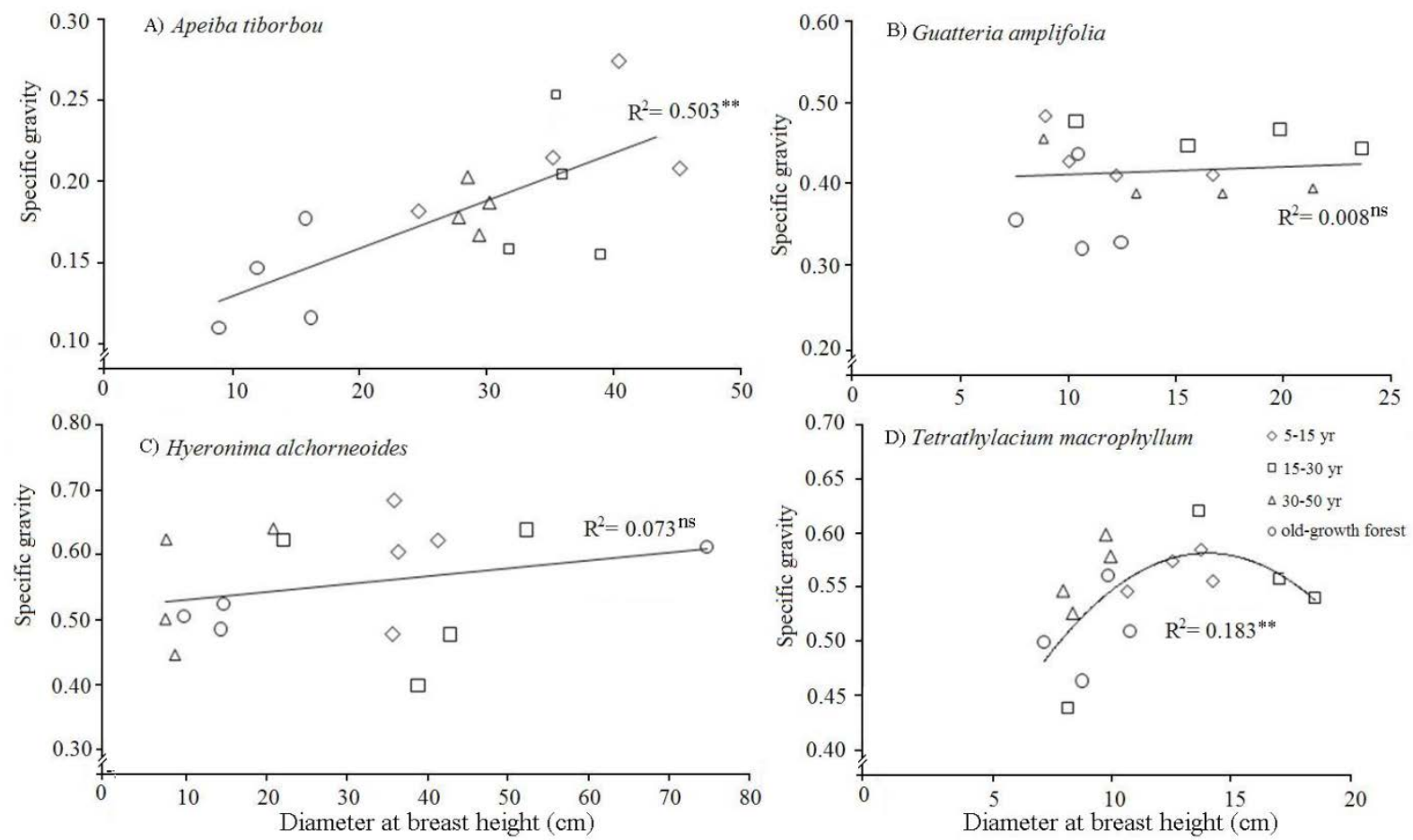

Figure 1. Effect of diameter at breast height on specific gravity from four species in four different succession stadiums in forests from the Corredor Biológico Osa, Costa Rica.

Efecto del diámetro a la altura del pecho sobre el peso específico básico en cuatro especies en 4 distintos estadios sucesionales de bosques del corredor Biológico Osa, Costa Rica.
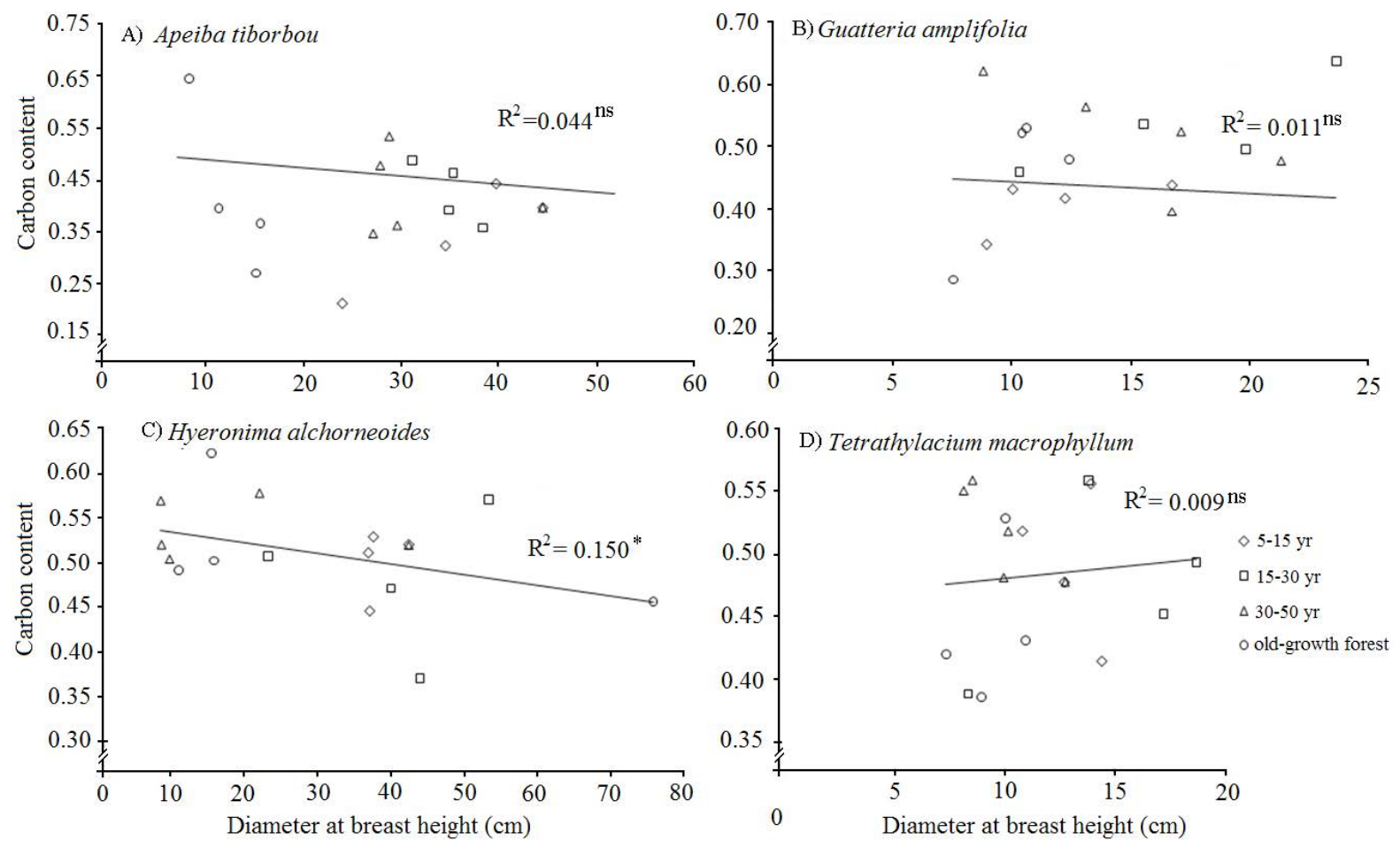

Figure 2. Effect of diameter, at $1.30 \mathrm{~m}$ from the ground, on the carbon content from four forest species in different succession stadiums from tropical forests in the Corredor Biológico Osa, Costa Rica.

Efecto del diámetro a $1,30 \mathrm{~m}$ del suelo sobre la fracción de carbono de cuatro especies forestales en cuatro distintos estadios sucesionales de bosques tropicales del corredor Biológico Osa, Costa Rica. 
Table 4. Specific gravity and carbon content of wood from four forest species in four successional stages from tropical forests in the Corredor Biológico Osa, Costa Rica.

Peso específico básico y fracción de carbono de la madera de cuatro especies forestales en cuatro estadios sucesionales en el Corredor Biológico Osa, Costa Rica.

\begin{tabular}{lccll}
\hline \multicolumn{1}{c}{ Species } & $\begin{array}{c}\text { Succession stage } \\
\text { (years) }\end{array}$ & $\begin{array}{c}\text { Diameter at breast } \\
\text { height }(\mathrm{cm})\end{array}$ & Specific gravity & $\begin{array}{c}\text { Carbon } \\
\text { content }\end{array}$ \\
\hline Apeiba tibourbou & Average of all stage & $28.62^{\mathrm{a}}$ & $0.18^{\mathrm{a}}(23.79)$ & $0.40^{\mathrm{a}}(25.78)$ \\
Guatteria amplifolia & & $23.74^{\mathrm{b}}$ & $0.41^{\mathrm{b}}(12.02)$ & $0.49^{\mathrm{b}}(18.84)$ \\
Hyeronima alchorneoides & & $29.34^{\mathrm{a}}$ & $0.55^{\mathrm{c}}(15.41)$ & $0.51^{\mathrm{b}}(11.68)$ \\
Tetrathylacium macrophyllum & & $11.77^{\mathrm{c}}$ & $0.54^{\mathrm{c}}(8.8)$ & $0.48^{\mathrm{b}}(12.78)$ \\
\hline Apeiba tibourbou & $5-15$ & $36.45(24.24)$ & $0.22^{\mathrm{a}}(18.84)$ & $0.34^{\mathrm{a}}(29.4)$ \\
& $15-30$ & $35.68(8.28)$ & $0.19^{\mathrm{b}}(23.95)$ & $0.42^{\mathrm{b}}(14.2)$ \\
& $30-50$ & $29.08(3.60)$ & $0.18^{\mathrm{b}}(8.14)$ & $0.43^{\mathrm{b}}(21.18)$ \\
\hline Guatteria amplifolia & old-growth forest & $13.28(25.89)$ & $0.14^{\mathrm{c}}(22.56)$ & $0.42^{\mathrm{b}}(38.1)$ \\
\hline Hyeronima alchorneoides & $5-15$ & $12.05(28.64)$ & $0.43^{\mathrm{ab}}(7.99)$ & $0.41^{\mathrm{a}}(10.81)$ \\
& $15-30$ & $17.40(32.88)$ & $0.46^{\mathrm{b}}(3.52)$ & $0.53^{\mathrm{b}}(14.38)$ \\
& $30-50$ & $15.18(35.31)$ & $0.41^{\mathrm{ac}}(8.09)$ & $0.55^{\mathrm{b}}(11.2)$ \\
& old-growth forest & $10.33(19.63)$ & $0.36^{\mathrm{d}}(14.76)$ & $0.45^{\mathrm{a}}(25.15)$ \\
\hline Tetrathylacium macrophyllum & $5-15$ & $37.73(7.07)$ & $0.60^{\mathrm{a}}(14.47)$ & $0.50^{\mathrm{a}}(7.44)$ \\
& $15-30$ & $39.38(31.93)$ & $0.53^{\mathrm{b}}(21.62)$ & $0.48^{\mathrm{a}}(17.46)$ \\
& $30-50$ & $11.50(57.01)$ & $0.55^{\mathrm{b}}(17.01)$ & $0.54^{\mathrm{b}}(6.73)$ \\
& old-growth forest & $11.88(30.87)$ & $0.53^{\mathrm{b}}(10.45)$ & $0.52^{\mathrm{ab}}(13.91)$ \\
\hline & $5-15$ & $13.25(12.08)$ & $0.56^{\mathrm{a}}(3.08)$ & $0.49^{\mathrm{a}}(12.37)$ \\
& $15-30$ & $14.80(31.17)$ & $0.54^{\mathrm{ab}}(14.03)$ & $0.47^{\mathrm{ac}}(15.15)$ \\
& $30-50$ & $9.45(10.56)$ & $0.56^{\mathrm{a}}(5.81)$ & $0.53^{\mathrm{b}}(6.74)$ \\
& old-growth forest & $9.58(16.19)$ & $0.51^{\mathrm{b}}(7.86)$ & $0.44^{\mathrm{c}}(13.9)$ \\
\hline
\end{tabular}

Legend: averages with equal letters do not present significant differences. Determined at $P>0.01$. The values in square parenthesis represent minimum and maximum values and normal parentheses represent variation coefficients.
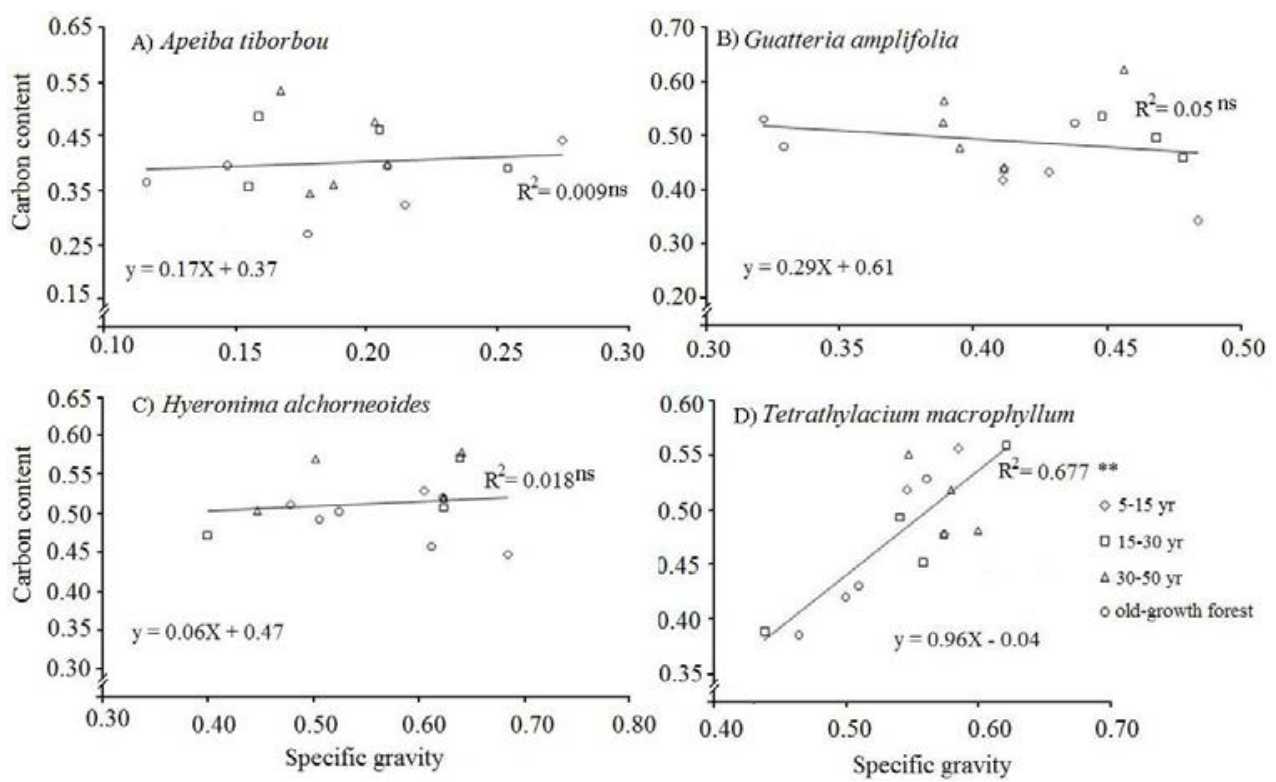

Figure 3. Effect of specific gravity on the carbon content of four forest species coming from different succession stadiums, in tropical forests of the Corredor Biológico Osa.

Efecto del peso específico básico sobre la fracción de carbono de cuatro especies forestales en diferentes estadios sucesionales de bosques tropicales del Corredor Biológico Osa. 
carbon content was higher in A. tibourbou than in the other species (table 3 ), which can be explained by the fact that sampled trees presented a high variety of diameters. Diameters for this species ranged from 9.00 to $45.30 \mathrm{~cm}$. Apeiba tibourbou trees sampled in old-growth forest had lower diameters in relation to earlier successional stages (table 3), indicating that these trees may have recently colonized a gap in the old-growth forest sites. However, this fact should be carefully studied, because H. alchorneoides presented large diameter variation.

Variation in carbon content was higher in A. tibourbou (coefficient of variation of $25.78 \%$ ) than in the other species (table 3), which can be explained by the fact that sampled trees present a high variety of diameters. Diameters for this species ranged from 9.00 to $45.30 \mathrm{~cm}$ (table 3). The highest variation is produced by trees sampled in primary forest. These trees presented lower diameter in relation to other successional stages (table 3 ), indicating that this species may have recently colonized a gap of primary forest.

Carbon content values obtained using the gross calorific value measures are numbers close to 0.50 , except for A. tibourbou which presents a value of 0.40 . These values coincide with values established for living organisms, i.e., 0.50 in carbon from dry weight of wood (Woodcock and Shier 2003). However, other studies such as Elias and Potvin (2003) also report variations in carbon content, from 0.45 to 0.53 ; a range that is close to values found for the four species studied in the different succession stages. A relevant aspect to point out from these values is that carbon content determination procedure is not detailed.

On the other hand, Kumar et al. (2010) also found carbon content variations in seven forest species used in India to produce firewood. The latter authors reported a range of 0.378 and 0.466 of carbon content, similar to that in the present study, but the determination of carbon content in the India species was done using the Walkley and Black method (Walkley and Black 1934), which is based on the oxidation of organic carbon shown by the sample in the presence of potassium dichromate in a strongly acid medium. This method was developed to determine carbon in soils and oxidizes only $77 \%$ of the total $\mathrm{C}$ in that condition; nevertheless, adjustment in the calculation must be done before using it for other materials. Other interesting research was carried out by Elias and Potvin (2003), who measured carbon content of 32 species of tropical trees in Panama using an automated elemental analyzer (model EA 1108, FISONS Instruments, Milan, Italy). They found that carbon content varied between 0.44 and 0.49 , with Ormosia macrocalyx and Tectona grandis flanking the lower and upper limits, respectively. Species specific differences (38.7\%) explained 10 times more variance than sites $(3.4 \%)$; while ecological groups did not account for any significant variation in carbon content (Elias and Potvin 2003).

Another relevant aspect is that in the present study, extractives were eliminated from wood. Many kinds of extractives are present in wood, though they are present in small amounts. They are constituted by fats, waxes, phenolics, terpenoids, alkanes, proteins and monosaccharides and derivatives and they can increase the specific gravity in from 0.0 to $3.0 \%$ (Hills 1987). When studying carbon content from 11 hard woods and 9 light woods through the combustion analysis, Ragland et al. (1991) determined that hard woods have an average of $50 \%$ in carbon content and light woods possess an average of $53 \%$. When analyzing the causes for such variation, the conclusion was that the differences are due to the lignin content and the extractives in each of the woods. Nogueria et al. (2008a), for example, calculated error estimations when the heartwood was not considered in biomass estimations. This variation reflects differences in species' chemical makeup. For instance, lipids, lignin, and proteins have elevated carbon concentrations, while organic acids and minerals contain little and no carbon, respectively (Poorter and Bergkotte 1992). And chemical wood composition varied with tree age, radial position and species longevity (Hills 1987). This statement points to the need to eliminate extractives from wood in our study, which eliminates variation and a source of error in the results among species. And thus it provides better carbon content estimation of natural forests.

Different parts of trees represent another variable that can affect carbon content. There is different carbon content in the leaf, trunk and roots (Poorter and Bergkotte 1992). Therefore, our results are limited to trunk as those values of carbon content can be different in the leaves or roots.

Some studies on tropical species show that diameter does not significantly affect specific gravity variation, as we found with G. amplifolia and H. alchorneoides. For example, Fearnside and Guimarães (1996) concluded that the tree's age is the most influential factor on specific gravity of wood, according to their study on specific gravity variation for Joannesia princeps Vell. in the Brazilian northwest. On the other hand, some researches had shown that diameter is not a determining factor for specific gravity. Wiemann and Williamson (1989) found that specific gravity radial increments of pioneer species in the lowlands of the Atlantic region in Costa Rica are associated with the age of the tree and not with its diameter, similar to the results with G. amplifolia and H. alchorneoides. Based on those results, Williamson and Wiemann (2010) state that stem diameter is not a good indicator of specific gravity in trees of pioneer species in tropical wet forests.

On their turn, Woodcock and Shier (2003) in a study on the southern Peruvian Amazonia in non-intervened forests found one single species (Pseudolmedia laevis Macbr.), out of 70 analyzed, with a positive relation between specific gravity and diameter variation. These authors mention that the relationship between specific gravity and diameter at breast height is due to a biomechanical response from the species to the need of providing strength and stiffness to the trunk as the tree develops with diameter increment; a situation that can be applied to the relationship found in A. tibourbou and T. macrophyllum in the present study. 
Butterfield et al. (1993) in a study on H. alchorneoides and Vochysia guatemalensis Donn Smith., at La Selva Biological Station, also confirm the positive relationship between specific gravity and diameter at breast height; as with A. tibourbou and T. macrophyllum (figures 1A and 1D).

Biomass estimation is derived from specific gravity (Nogueira et al. 2008) and it is correlated with carbon content. However, it was mentioned above that there is a relationship between specific gravity and diameter at breast height in A. tibourbou and T. macrophyllum, in contrast to G. amplifolia and $H$. alchorneoides where no difference was established. Thus, if we do not consider the relation between specific gravity and diameter at breast height in A. tibourbou and T. macrophyllum in different successional stages when estimating biomass from specific gravity, we could affect biomass calculations or biomass errors. For example, specific gravity of A. tibourbou trees is approximately 0.15 in the first stage of secondary forestry, but the adult from natural forest trees reaches approximately 0.30 (twice those values of the juvenile stage). Then, if we do not consider the specific gravity variation, biomass estimations will vary in $100 \%$ from juvenile to mature stage.

Results show that there are different theories on factors that influence specific gravity; maybe it depends more on the species and their particular biological characteristics. For example, Muller-Landau (2004) analyzed specific gravity in four sites distributed in different countries: La Selva Biological Station (Costa Rica), Barro Colorado Island (Panama), Cocha Cashu Biological Station (Peru) and Kilómetro 41 (Manaos, Brazil). The author found that specific gravity was not dependent on soil fertility, temperature, precipitation or seasonality, and mentions that species biology must be studied separately to establish which variables influence this characteristic.

The low relationship between carbon content and diameter at breast height in all studied species differs from other studies. For instance, Cubero and Rojas (1999) report an increase tendency in the carbon content as the trees age increases in plantations of Gmelina arborea Roxb., Bombacopsis quinata (Jacq.) Dugand and Tectona grandis L. However, this result must be considered with caution, as it deals with short ages spans (maximum values: 12, 12 and 15 years, respectively). Furthermore, as it happens with specific gravity, carbon content can also be more significantly influenced by the tree's age than by tree diameter (figure 2).

Different studies show that an increase in diameter produces an increase in biomass and therefore a greater amount of stored carbon. For example, Loaiza et al. (2010), in their work on biomass and carbon stored in Pinus patula Schiede ex Schltdl. et Cham. and Tectona grandis from different forests in Colombia, state that the amount of carbon stored in biomass increases with diameter enhancement in trees; not seen in carbon content. On the other hand, Clark et al. (2003), when annually analyzing carbon dynamics in six forest species growing in a tropical wet forest in Cos- ta Rica during a period between 1984 and 2000, determined that carbon fixation on a tree does not have a relation with variations in annual diametric increments; therefore, through this behavior it was concluded that diameter has no positive correlation with carbon balance. However, this information must be carefully analyzed because they did not measure carbon content. They assume a constant $50 \%$.

Previous results, as well as those obtained through this research, suggest that carbon content is an intrinsic characteristic of each species (Elias and Potvin 2003). And it may depend on other factors, as taxonomy and genus variation (Martin and Thomas 2011) or age to secondary forest (Hughes et al. 1999) from the forestry perspective and lignin/cellulose ratio (Pettersen 1984), variation in nonstructural carbohydrate concentrations and carbon content volatile (Thomas and Malczewski 2007) from the chemical perspective. Besides, carbon content depends on geographical variations, and environmental and growth conditions. Elias and Potvin (2003) analyzed 32 neotropical tree species and showed that the environmental and (or) growth factors explaining variation in trunk carbon concentration and species respond differently to environmental factors. However, despite these factors, it was found that carbon content does not depend on tree diameter and it affected mainly in the juvenile stage. This behavior makes it really easy to determine carbon content in tropical forest species as it will not depend on a great variety of tree diameters, which will always be a part of tropical forests. However, it is necessary to know the geographical and environmental variation of studied species to predict the real carbon content. Similarly, error estimation of carbon content is related with good quality information of specific gravity determination; therefore further research about this relationship appears as necessary.

As stressed before, the 5-15 and 15-30 stages were statistically different to other stages (table 4) and 30-50 stage and primary forest stages in almost all species did not show significant differences in carbon content; thus indicating that over 30 years carbon content and specific gravity would reach levels similar to those from primary forest and after 30 years it does not depend on the forest stage where species are located. In other studies, but using biomass accumulation as an indicator of maturity in different successional stages, a pattern similar to the one found in this study was shown. However, age of successional stages was different when contrasted with our study. For example, Hughes et al. (1999) studying a secondary forest in Tuxtlas, Mexico, found that secondary forests reach biomass accumulation similar to that from primary forests when they reach 73 years old. On the other hand, Fearnide and Guimarães (1996) studied secondary forests in Brazil using biomass parameters and found that a secondary forest reaches its maturity at 100 and $144-189$ years (Fearnide and Guimarães 1996).

For species over 30 years old, it was established that carbon content is an intrinsic characteristic of each spe- 
cies. Lammlom and Savidge (2003), after studying carbon content from 41 North American forest species, stated that this parameter depends on the chemical and anatomical composition of each species; therefore, it is reasonable that each species has characteristic carbon content that does not depend on the succession stage. Similarly, Vaccaro et al. (2003), through studies on mature forests and secondary vegetation in Argentina, found that carbon stored in biomass increases through time, but carbon content did not vary with the different succession stadiums. Once again, this result from the forests in Argentina matches the results found by Lammlom and Savidge (2003) in North America and the four species analyzed in the present study. On the other hand, studies at the genetic level have shown that the amount of carbon is hereditary in species; thus supporting the hypothesis that each species has its own characteristics. Implications of the previous result will allow for the determination of carbon content in one species, just by measuring its carbon content in succession stages over 30 years and then extrapolating the other stages, considering, however, the biomass increase with diameter increase.

The lack of correlation relation between specific gravity and carbon content observed in A. tibourbou, G. amplifolia and $H$. alchorneoides and the relationship found in T. macrophyllum must be considered as highly important in future carbon determinations, not only in its fraction of the biomass, but also in the amount of carbon stored in a tree. The mathematical model between carbon content and specific gravity was carbon content $=0.97 *$ specific gravity-0.04 (figure 2). In the case of species that do not show any relation to specific gravity, the future carbon content or stored carbon assessment is simply using the carbon content value obtained in the present study and not considering the possible variation of specific gravity for that species due to the nonexistent relation between those parameters. In future T. macrophyllum determinations of carbon content, the specific gravity effect on these parameters must be considered because there is a correlation among them. For the carbon content correction by specific gravity, the best adjustment obtained equation can be used (figure 1).

\section{CONCLUSIONS}

Carbon content and specific gravity are highly variable among the studied tropical tree species and they are influenced by forest succession stages of secondary forest for all species. Diameter at breast height does not influence carbon content or specific gravity in G. amplifolia and $H$. alchorneoides, but the diameter was correlated with specific gravity in A. tibourbou and T. macrophyllum. The most interesting result was that carbon content was correlated with specific gravity in T. macrophyllum; however, it was not correlated in the other tropical species. This result establishes that carbon content or specific gravity is an intrinsic property of each species and variable with diameter at breast height, especially in A. tibourbou, G. amplifolia and T. macrophyllum. Likewise, carbon content is correlated with specific gravity in T. macrophyllum. Carbon content determination in three tropical species looks like complex, because it is influenced by successional stages, diameter at breast height or specific gravity.

On the other hand, specific gravity is an important variable in estimates of forest biomass and greenhouse-gas emissions from land-use change. However, these wood properties varied with diameter at breast height in different successional stages in secondary forest for A. tibourbou and T. macrophyllum. Thus, the variation in specific gravity will also affect biomass calculations in species of secondary forest, even if carbon content does not change, when this variation is not taken into account in trees of A. tibourbou and T. macrophyllum from different successional stages. But more accurate, biomass estimation decreased in G. amplifolia and H. alchorneoides trees from different successional stages due to the lack of relationship between diameter at breast height and specific gravity.

\section{ACKNOWLEDGMENTS}

The authors wish to thank Vicerrectoría de Investigación y Extensión del Instituto Tecnológico de Costa Rica (ITCR). We appreciate the collaboration of Guido Saborío, biologist from the Osa Biodiversity Center $(\mathrm{OBC})$ and parataxonomist Reinaldo Aguilar for their helping in the identification of species.

\section{REFERENCES}

ASTM (American Society for Testing and Materials, USA). 2003a. Standard test method for preparation of extractivefree wood. 16 p. (ASTM D 1105-97).

ASTM (American Society for Testing and Materials, USA). 2003b. Standard test method for gross calorific value of coal and coke. 8p. (ASTM D 5865-04).

ASTM (American Society for Testing and Materials, USA). 2003c. Standard test methods for specific gravity of wood and wood-base materials. 12 p. (ASTM D 2395-02).

Butterfield RP, RP Crook, R Adams, R Morris. 1993. Radial variation in wood specific gravity, fiber length and vessel area for two Central American hardwoods: Hyeronima alchorneoides and Vochysia guatemalensis: natural and plantation-grown trees. IAWA Journal 14: 153-161.

Calvo J, A Sánchez. 2007. Estudio de monitoreo de cobertura forestal de Costa Rica 2005. Oficina Nacional Forestal. Consulted 11 apr. 2009. Available in http://www.sirefor.go.cr

Chave J, H Muller-Laudau, T Baker, T Easdale, H Steege, C Webb. 2006. Regional and phylogenetic variation of wood density across 2456 neotropical species. Ecological Applications 16:2356-2367.

Clark D, S Piper, C Keeling, D Clark. 2003. Tropical rain forest tree growth and atmospheric carbon dynamics linked to interannual temperature variation during 1984-2000. PNAS 100: 5852-5857.

Cubero J, S Rojas. 1999. Fijación de carbono en plantaciones 
de melina (Gmelina arborea Roxb.), teca (Tectona grandis L.f:) y pochote (Bombacopsis quinata Jacq.) en los cantones de Hojancha y Nicoya, Guanacaste, Costa Rica. Tesis Licenciatura. San José, Costa Rica. UNA. 95 p.

Figueroa CJ, A Etchevers, A Barra, A Velázquez, M Acosta. 2005. Concentración de carbono en diferentes tipos de vegetación de la Sierra Norte de Oaxaca. Terra Latinoamérica 23: 57-64.

Fearnside PM, WM Guimarães. 1996. Carbon uptake by secondary forests in Brazilian Amazonia. Forest Ecology and Management 80: 35-46.

Elias M, C Potvin. 2003. Assessing inter- and intra-specific variation in trunk carbon concentration for 32 neotropical tree species. Canadian Journal of Forest Research 33: 10391045.

Hillis WE. 1987. Heartwood and tree exudates. Berlin, Germany. Springer Verlag. 268 p.

Hughes RF, JF Kauffman, J Jaramillo. 1999. Biomass, carbon, and nutrient dynamics of secondary forest in a humid tropical region of Mexico. Ecology 80: 1892-1907.

Kumar R, KK Pandey, Chandrashekar, S Mohan. 2010. Effect of tree-age on caloric value and other fuel properties of Eucalyptus hybrid. Journal of Forestry Research 21: 514-516.

Lammlom SH, RA Savidge. 2003. A reassessment of carbon content in wood: variation within and between 41 North American species. Biomass and Bioenergy 25: 381-388.

Loaiza J, J Rodríguez, M. Ramírez, A Lema. 2010. Estimation of biomass and carbon stocks in plants, soil and forest floor in different tropical forests. Forest Ecology and Management 260: 1906-1913.

Martin AR, SC Thomas. 2011. A reassessment of Carbon content in tropical trees. PLOS ONE 6(8): 1-9.

Muller-Landau H. 2004. Interspecific and inter-site variation in wood specific gravity of tropical trees. Biotropica 36: 20-32.

Nelson DW, LE Sommers. 1975. A rapid and accurate procedure for determination of carbon organic in soils by wet combustion. Soil Science 111: 330-336.
Nogueira EM, PM Fearnside, BN Nelson, R Barbosa, EW Hermanus. 2008. Estimates of forest biomass in the Brazilian Amazon: New allometric equations and adjustments to biomass from wood-volume inventories. Forest Ecology and Management 256: 1853-1867.

Pan Y, RA Birdsey, J Fang, R Houghton, PE Kauppi, WA Kurz, OL Phillips, A Shvidenko, SL Lewis, JG Canadell. 2011. A large and persistent carbon sink in the world's forests. Science 333: 988-993.

Pettersen RC. 1984. The chemical composition of wood. In Rowell R ed. The chemistry of solid wood. Madison, Wisconsin, USA. American Chemical Society. p. 57-126.

Poorter H, M Bergkotte. 1992. Chemical composition of 24 wild species differing in relative growth rate. Plant Cell Environmental 15: 221-229.

Ragland KW, DJ Aerst, AJ Baker. 1991. Properties of wood for combustion analysis. Bioresource Technology 37: 161-168.

Thomas SC, Malczewski G. 2007. Wood carbon content of tree species in Eastern China: Interspecific variability and the importance of the volatile fraction. Journal of Environmental Management 85: 659-662.

Vaccaro S, M Arturi, J Goya, J Frangi, G Piccolo. 2003. Almacenaje de carbono en estadios de la sucesión secundaria en la provincia de Misiones, Argentina. Interciencia 28: 521-527.

Walkley A, IA Black. 1934. A critical examination of a rapid method for determining soil organic matter and a proposed modification of the chromic acid titration method. Soil Science 37:29-37

Wiemann MC, GB Williamson. 1989. Wood specific gravity gradients in tropical dry and montane rain forest trees. American Journal of Botany 76: 924-928.

Williamson B, M Wiemann. 2010. Age-dependent radial increases in wood specific gravity of tropical pioneers in Costa Rica. Biotropica 42: 590-597.

Woodcock DW, AD Shier. 2003. Does canopy position affect wood specific gravity in temperate forest trees? Annals of Botany 91: 529-5370. 
